\title{
Effects of Cooperative Learning on Students at An Giang University in Vietnam
}

\author{
Van Dat Tran (Corresponding Author) \\ Education 2 Building, Faculty of Education, La Trobe University, Australia \\ Melbourne (Bundoora), Vic 3086, Australia \\ Tel: 61-394-792-611 E-mail: v2tran@students.latrobe.edu.au \\ Ramon (Rom) Lewis \\ Education 2 Building, Faculty of Education, La Trobe University, Australia \\ Melbourne (Bundoora), Vic 3086, Australia \\ Tel: 61-394-792-611 E-mail: r.lewis@latrobe.edu.au
}

Received: September 4, 2011

Accepted: September 22, 2011 Published: February 1, 2012

doi:10.5539/ies.v5n1p86

URL: http://dx.doi.org/10.5539/ies.v5n1p86

\begin{abstract}
This study investigates the effects of jigsaw cooperative learning on the achievement and knowledge retention of 80 final-year Vietnamese mathematics students, as well as reporting their attitudes toward this form of learning. These tertiary students were divided into two matched groups of 40 to be taught by the same lecturer. In the experimental group, jigsaw learning was employed, while in the control group, lecture-based teaching was used over the six weeks of instruction. The results showed that students in the experimental group, who perceived their instruction as more cooperative and more student-centered, had significantly greater improvement on both achievement and retention measures than did the students in the control group. A survey revealed favorable responses toward jigsaw learning. The major findings of this study support the effectiveness of jigsaw learning for students in Vietnamese higher education institutions.
\end{abstract}

Keywords: Cooperative learning, Jigsaw learning, Achievement, Retention, Attitudes

\section{Introduction}

The most appropriate pedagogical approaches should promote not only students' memory and comprehension, but also facilitate their acquisition of competencies, skills of communication, independent thinking and team work (DES, 2003; NASRV, 2008). While effective teaching methods such as discussion and cooperative learning (CL) could be options for teachers seeking to improve student learning, almost all the traditional teaching approaches used in schools around the world include lectures, demonstration, and competition in which learners are likely to be hindered by working together when attempting to maximize their own learning (Sousa, 2006; Johnson \& Johnson, 2009). Recently, although there have been efforts to change from teacher-centered approaches to student-centered approaches in an attempt to provide students with greater skills and knowledge, lecture-based teaching continues to be the most prevalent teaching method in Vietnamese higher education institutions (VHEI) (MOET, 2009; Thanh-Pham, 2010a\&b). In the traditional classroom setting, an emphasis on lower-order thinking competencies such as memorization, comprehension and application skills rather than on higher-order thinking such as analysis, synthesis and evaluation skills has been argued to be inappropriate to the needs of students in VHEI (Director, Doughty, Gray, Hoperoft \& Silvera, 2006). In order to encourage students to work together rather than compete, to improve their achievement and knowledge retention an alternative to lecture-based teaching could be CL (Magnesio \& Davis, 2010; Mehra \& Thakur, 2008). This approach has also been reported to promote more positive student attitudes toward their learning (Whicker \& Nunnery, 1997; Johnson \& Johnson, 2008), enhance more positive relationships between participants (Johnson \& Johnson, 2005) and develop self-esteem, cohesiveness, and learning skills (Sahin, 2010; Slavin, 2011).

\section{Literature Review}

CL comprises "instructional methods in which teachers organize students into small groups, which then work together to help one another learn academic content" (Slavin, 2011, p.344). CL consists of five basic elements: 
positive interdependence, promotive interaction, individual accountability, teaching of interpersonal and social skills and quality of group processing. CL has demonstrated the academic, social, affective and psychological growth of students who work together in groups (Johnson \& Johnson, 2008).

\subsection{Achievement}

CL has been reported to produce better achievement than competitive learning environments (effect size $=0.67)$ or individualistic learning (effect size $=0.64$ ) (Johnson \& Johnson, 2005). Using effect size as the measure of CL effects on achievement, Slavin (1990) analyzed 68 studies and found that forty-eight of the sixty-eight experimental and control comparisons supported CL groups (72\%); and only eight (12\%) supported control groups. Slavin (1996) reviewed an additional 99 studies and reported that sixty three (63\%) of the ninety-nine comparisons supported the treatment groups' impact on achievement and only five (5\%) identified the control groups as superior. Similarly, using voting, effect-size, and z-score for meta-analyses, Johnson \& Johnson (1999) reviewed 122 studies and yielded 286 empirical findings, which showed students with CL, on average, achieved academically at the 80th percentile of students experiencing competitive or individualistic learning. These findings validate the extensive review of 323 studies yielding 1,691 findings conducted by Johnson \& Johnson (2002), which reported that students in cooperative situations academically outperformed students in individualistic settings (effect-size $=0.75$ ). Similar findings have also been noted in recent studies (Yamarik, 2007; Kilic, 2008; Doymus, 2008a\&b; Adeyemi, 2008; Sahin, 2010; Doymus, Karacop \& Simsek, 2010; Bertucci, Conte, Johnson, \& Johnson, 2010; Slavin, 2011) which report that students in CL groups have higher adjusted posttest mean scores than those in conventional lecture groups. The findings of the above research studies have led to strong arguments by various authors that $\mathrm{CL}$ is an effective teaching pedagogy for schools.

\subsection{Knowledge Retention}

Sousa (2006) reports the average percentage of material retained 24 hours after receiving instruction via different learning methods. A "lecture" results in an average knowledge retention of only $5 \%$. This does not come as a surprise because a lecture generally provides for minimal active participation or mental rehearsal from students. Other methods show more retention, for example $10 \%$ for reading; $20 \%$ if audio-visual; $30 \%$ for demonstration and $50 \%$ for a discussion group. Methods that require students to practice by doing, and teach others result in $75 \%$ to $90 \%$ material retention. Teaching others and elaborating ideas are the main features of CL (Kagan \& Kagan, 2009; Slavin, 2011). O'Donnell (1996; 2000) claims the effectiveness of cognitive elaboration in cooperative situations is because it prepares the learners for cognitive re-structure and rehearsal to enhance learning tasks. Consequently it has been argued that in cooperative situations, students retain more knowledge when they are offered more explanation and elaboration (Zakaria, Chin \& Daud, 2010; Webb, 2008). Recent studies (Iqbal, 2004; Mehra \& Thakur, 2008), report such superior knowledge retention. In Iqbal's (2004) study, a significant difference at .05 level was found between the mean scores on a retention test of low achievers of the CL group and that of the comparison group. Similarly, in Mehra \& Thakur's (2008) study, students within the cooperative group significantly outperformed students in the lecture-based setting when it came to recalling what was taught. The results of some additional studies (Chianson, Kurumeh \& Obida, 2010; Kvam, 2000; Tanel \& Erol, 2008; Nassal, 2009; Nichols, 2002; Webb, 2008) also show that lecture-based teaching is less effective in improving knowledge retention than cooperative learning methods which involve students teaching students.

\subsection{Social, Affective and Psychological Outcomes}

CL has been linked to a range of positive social, affective and psychological outcomes, including social support, the quality of student relationships, attitude to learning, learning skills, and self-esteem. The results of some recent studies (Johnson \& Johnson, 2005; Johnson \& Johnson 2006; Bertucci et al., 2010) show that in cooperative learning situations students displayed a higher perception of social support, both personally and academically, than students in competitive (effect size $=0.62$ ) or individualistic (effect size $=0.70$ ) situations. Social support has been showed to promote achievement, productivity and retention (Johnson \& Johnson 2006). CL also promotes more positive relationships among participants than does a competitive learning environment (effect size $=0.67$ ) or individualistic learning (effect size $=0.60$ ) (Johnson \& Johnson, 2005). Such positive relationships result in an increase in motivation and persistence in working toward the shared goals, satisfaction, commitment to group goals, productivity and personal responsibility for achievement (Johnson \& Johnson, 2006; Slavin, 2011). In addition, CL promotes more positive attitudes toward learning than do competitive (effect size $=0.57$ ) or individualistic learning environments (effect size $=0.42$ ) because students work together for shared goals (Johnson \& Johnson, 2005). The cooperative context also enhances more use of problem-solving, critical thinking and oral communication skills (Johnson, 2003) because students experience different ideas during learning tasks (Abrami \& Chambers, 1996). Furthermore, CL facilitates greater improvement in self-esteem than does competitive (effect size $=0.58$ ) or 
individualistic learning environments (effect size $=0.44)($ Johnson \& Johnson, 2005). In some studies (Kilic, 2008; Bertucci et al., 2010) students' self-esteem increased in cooperative situations because students were involved in cooperative efforts. The findings reported above validate the results of other studies (Mulryan, 1994; Whicker \& Nunnery, 1997; Nhu-Le, 1999; Vaughan, 2002; Gillies, 2006; Zain, Subramaniam, Rashid \& Ghani, 2009; Kose, Sahin, Ergun \& Gezer, 2010; Le, 2010; Thanh-Pham, 2011) which report that CL promotes more use of higher-level learning skills, more positive cohesion among participants, higher self-esteem in learning and more positive feelings toward the learning task. In summary, it may be argued that CL appears to be an effective way to engage students in learning.

\section{Research Hypotheses}

The preceding review of literature shows that in comparison with other teaching methods, CL appears to have a greater likelihood of improving achievement, knowledge retention and positive attitudes of students toward their own learning. However, the review also shows that almost all studies which supported the effectiveness of CL were conducted in the environment of western education. Hence, it is less clear whether CL can be successfully applied in other countries, in which social, religious, educational and cultural systems are likely to be different from those of western countries. In addition, while CL is viewed as an effective method for many different subject areas at all educational levels, most studies applied CL in Natural Sciences at the levels of primary and secondary education. Furthermore, very few research studies have investigated the effectiveness of CL on student learning in the setting of Vietnamese higher education institutions. Some studies (Nhu-Le, 1999; Le, 2010; Thanh-Pham, 2011) were located which utilized a qualitative, survey methodology to investigate achievement and attitudes of Vietnamese EFL (English Foreign Language) students who experienced CL. These studies also argued for the effectiveness of CL in promoting students' achievement and positive attitudes toward learning.

The current study adds to the literature by empirically investigating the impact of CL in Vietnam. Specifically, it reports the results of an experimental study designed to determine if jigsaw learning is more effective than lecture-based learning in improving achievement, knowledge retention, and attitudes of university students. The results of the study may encourage Vietnamese teachers to pay more attention to designing cooperative learning groups thereby providing students with more opportunities to discuss learning tasks and to practice skills. The participating students were undertaking a Graduate program focusing on Managing Administration and Education (MAE), in the Faculty of Education at An Giang University in Vietnam, where learning is generally perceived to be passive (Director, et al., 2006) and the dominant pedagogical method is lecture (MOET, 2009).

The positive effects of $\mathrm{CL}$ on academic and social variables, found in the literature, have led to the following primary hypotheses. Hypothesis 1: Students who are taught by jigsaw learning will demonstrate greater MAE achievement than those taught through lecture-based teaching. Hypothesis 2: Students who are taught by jigsaw learning will have greater retention of MAE information taught than those taught through lecture-based teaching. Hypothesis 3: Students' perception of the quality of their instruction will not differ, whether taught by jigsaw learning or taught through lecture-based teaching. Hypothesis 4: Students' taught by jigsaw learning will perceive more frequent use of group processes during the instruction than those taught through lecture-based teaching. Hypothesis 5: Students who are taught by jigsaw learning will have positive attitudes towards this learning.

\section{Research Method}

\subsection{Participants}

This study used a sample of 80 final-year students comprising 32 females and 48 males, from two mathematics classes in the Faculty of Education at An Giang University in Vietnam. The 80 students were matched into two groups of 40, based on the variables of age, gender and GPA scores. Matching was employed to create comparable groups and when there are as many as 40 people participating in each group extraneous differences are likely to be "washed out" (Suter, 2006). A matching technique (Creswell, 2009) was utilized to divide students into the experimental and control groups, since variables such as age, gender, and academic ability would probably affect students' academic achievement and their attitudes (Best \& Kahn, 1998). In this study these variables were deliberately controlled by the matched sampling.

The end result of this matching procedure was that, in total, the participants in both groups were similar, or "equated as nearly as possible", or "very similar on the matched variables" (Neuman, 2006). In the experimental group of 40 students, there were 24 males and 16 females with a mean age of 21.50 and a mean GPA score of 6.45 , while in the control group of 40, there were 24 males and 16 females with a mean age of 21.53, and a mean GPA score of 6.51. The results of a one-way ANOVA analysis showed no significant differences between groups' GPA scores $(\mathrm{F}(1,78)$ $=.047 ; \mathrm{p}>.05)$ over the last three years. The two groups were also pre-tested on MAE course knowledge to validate equivalence in academic ability before the treatment. This 'prior knowledge' measure is also used as a covariate to 
allow an estimation of increase in students' academic achievement. Although the mean scores on the knowledge measure of MAE (pre-test) for the control group $(\mathrm{M}=6.76, \mathrm{SD}=.914, \mathrm{~N}=40)$ was higher than that for the experimental group $(\mathrm{M}=6.61, \mathrm{SD}=.884, \mathrm{~N}=40)$, the ANOVA shows there is no statistically significant difference on MAE pre-test scores between two groups $(\mathrm{F}(1,78)=.556 ; \mathrm{p}>.05)$. These results indicate that students in both the experimental group and control group had similar academically general knowledge on MAE before the experiment commenced.

\subsection{Instruments}

\subsubsection{Tests}

As stated above, in this study, a pre-test on MAE knowledge was used to validate the equivalence of the academic ability of the groups before the treatment, and was also used as a covariate to allow an estimate of the increase in achievement after the treatment. This test comprised 30 items focused on the students' general knowledge of the MAE course. A post-test comprising 30 items focussing on the basic knowledge of the MAE course was used to measure achievement after the treatment. Using Bloom's cognitive domain of taxonomy, the 30 items in both tests commenced with the recall of factual information ( 5 items), proceeding to the lowest comprehension level (5 items), and then advancing to complex levels of application ( 5 items), analysis ( 5 items), synthesis (5 items), and evaluation ( 5 items). A retention test (the same as the post-test) was used to measure knowledge retention. The maximum score for the knowledge component of both tests was 10. All 30 items in both tests were presented in a multiple-choice format. Each item had four alternative choices for the correct answer. The post-test content was carefully chosen to ensure that all items were based on concepts and principles taught to both groups. There is no item on a problem that had been discussed in one group but not the other.

The content validity of both tests was checked and strengthened by asking two MAE teachers at An Giang University to review all the items in the Vietnamese language and give suggestions for improvement. These experts also compared the MAE content to be covered in the study with what was measured by the tests. Both tests were piloted with mathematics students $(\mathrm{N}=30)$ who had taken the MAE course the year before. Using Cronbach's Alpha, the reliability of the pre-test was 0.71 , and 0.86 for the post-test. It was, therefore, accepted that both tests had good reliability and discriminatory power. To avoid any possible bias in marking, the ID of students was removed from their answer papers and the test papers of the groups were mixed together before they were marked by two MAE teachers. To reduce expectancy influence from the researcher when marking the papers, two MAE teachers were invited to mark all the test papers. Neither marker knew whether the research participants were in the control group or the experimental group.

\subsubsection{Questionnaires}

Two survey questionnaires were administered after the treatment as part of this study. One was designed to measure students' perception of instruction in both the experimental and control groups, and the other was given to the treatment group only, to measure students' attitudes toward jigsaw learning. The first questionnaire, containing 26 items, measured a range of elements of the instruction offered to students in both groups. Among these items there were some which were meant to be equally applicable to the instruction in both groups (e.g. teacher appeared friendly, teacher made the lesson interesting, teacher seemed enthusiastic about the subject, students understood the lesson well) and others which focused on the extent to which students experienced cooperative group-work had the opportunity to learn from each other (e.g. students discussed the learning material with other students, students learned in group, students listened attentively to lecture, students watched PowerPoint presentation). For each item, respondents indicated on a four point scale the frequency with which it occurred by choosing from Never, Hardly Ever, Sometimes, Often and Very Often, coded 1 to 5 respectively. A survey questionnaire must be designed so that all participants have a clear understanding of the information that the researcher intends to collect from them (Neuman, 2006). Therefore, both the questionnaires in the Vietnamese language were reviewed and enhanced by two outside experts, experienced in educational research, in the same field at An Giang University in Vietnam. Neither was involved in this research study. The two experts helped refine the questionnaires by designing statements, clarifying language, and identifying unnecessary statements.

A factor analysis (Oblimin rotation) performed on the 26 items on the first questionnaire indicated a four factor solution, based on a Scree test. All but one item displayed positive factor loadings (greater than 0.4 ) on one and only one of the four factors. This item was placed into the factor on which it had the greater loading. The students' responses to these four sets of items were checked for internal consistency by computing respective Cronbach Alpha coefficients, and two items were removed from consideration as their removal increased the magnitude of the Cronbach alpha coefficient of the scale with which they were associated. Table 1 below defines each of the four scales produced from the remaining 26 items and reports their reliability. As indicated in Table 1, the scales have 
been called Generic Teaching Skills (GTS), Student Centered Learning (SCL), Engagement with Learning (EL), and Powerful Teacher (PT).

\section{Insert Table 1 here}

The second questionnaire included one closed and two open questions, given to the treatment group only, to investigate students' attitudes toward jigsaw learning in their MAE unit. The first question assessed students' attitudes, using the alternatives: liked a lot, liked a little, not sure, disliked a little and disliked a lot. The last two questions indicated the degree to which students liked or disliked jigsaw process. To attest to the reliability of the findings which emerged from the narrative account of the two open questions, an auditor (Creswell \& Miller, 2000) was invited to ensure correct interpretations.

\subsection{Design}

The Pre-test-Post-test Nonequivalent Comparison-Group Design (Table 2) "helps researchers test for causal relationships in a variety of situations in which the classical design is difficult or inappropriate" (Neuman, 2006, p.256). The present study used this design to test the cause and effect relationship between the treatment variable (jigsaw learning pedagogy and lecture-based teaching pedagogy) and the outcome variables (academic achievement, knowledge retention, perception of instruction, and attitudes towards jigsaw learning in MAE course). Since the subjects were not randomly assigned to treatment or control groups, some threats to the external and internal validity were possible (Basit, 2010). These threats include selection bias, selection-maturation, selection-instrumentation, selection-regression and selection-history (Creswell, 2009). Accordingly, these threats will be considered. As both the experimental and control groups took the same pre-test (before the experiment) and post-test (after the experiment), and the experiment covered the same time period for all subjects, testing, instrumentation, maturation, and mortality are not internal-validity problems (Ary, Jacobs, \& Razavieh, 2002). Also, the researcher alone taught both the treatment and control group, therefore history is not a problem in this study, since differences among teachers cannot systematically influence post-test results although history may contribute slightly to retention test comparisons (Ary et al., 2002). Ary et al., further state that if the pre-test scores are similar and selection-maturation interaction and regression can be shown to be unlikely explanations of post-test differences, the results of this quasi-experimental design are quite credible. Even if the group means are noticeably different before treatment, a nonequivalent control group is better than no control group at all (Ross, Morrison \& Lowther, 2005).

\section{Insert Table 2 here}

\subsection{Experimental Procedure}

The experimental procedure involved a number of steps. Prior to the beginning of the academic year of 2010-2011, before classes were scheduled, 80 final-year mathematics students at An Giang University were selected for the study. These students were divided into two matched groups of 40 , based on the three variables of age, gender and GPA scores. The group size of 40 students was the average size of mathematics classes at An Giang University. Each group became an MAE class. To validate equivalence on academic ability in MAE between the two groups, a pre-test on MAE was administered to the control and experimental groups before the treatment. One group was randomly chosen to receive lecture-based teaching and acted as the control group, and the other received jigsaw learning and acted as the experimental group in an MAE course for six weeks. The MAE course chosen for this study builds up core knowledge necessary for the management of administration and educational institutions. The MAE course comprised six units (1. Vietnamese Law and State; 2. Public service and servants; 3. Policies of Vietnamese State in Education; 4. Education Law; 5. Regulations for general education; 6. The practice of Education in An Giang Province). Each unit taught within one week. Each unit covered four subunits and each subunit focused on a different aspect of knowledge. Therefore, the content of each unit may be divided into independent subunits, so that each subunit may be learned by a member of the group in the treatment group. This satisfied the demands of applying the jigsaw learning technique in the classroom designed by Aronson, Blaney, Stepan, Sikes \& Snapp (1978).

In the control group, students learned the MAE content as a result of lecture-based teaching in logical steps, and they worked as a whole class group. The instructor's role was one of information transmitter. The main interaction was between the teacher and the students. The instructor determined the speed of delivery, as he taught the material and decided when questions were to be answered and tests were to be administered. It was the students' responsibility to master the subject and to be ready to do the tests.

In the experimental group, the instructor attempted to guide students to learn the MAE content using the jigsaw technique. This technique helps students break learning materials into manageable learning pieces, and then has students teach others the piece they have mastered, consequently combining these pieces into one whole. The 
instructor's role was one of learning facilitator. The interactions were between the learning materials and the students, between students, and between students and the teacher. In this group, the instructor applied the following eight steps. Firstly, the objectives of the subject matter were identified. Secondly, the learning materials were organized. Thirdly, ten home groups of four students were formed, and eight jigsaw groups of five were formed from the ten home groups. Fourthly, the instructor explained the process. Each unit was divided into four independent subunits and each was given to a different member of a home group. Each student in a home group received a different subunit to study. Each student then read to the other home group members the title of the subunit assigned to him or her, so that all of the group members become acquainted with the sequence of the learning material. Fifthly, when students understood the lesson structure, they were asked to move to new groups called jigsaw groups. There were eight jigsaw groups of five students formed from the ten home groups. Sixthly, the instructor had students help one another to learn their same specialist sections. Consequently five students helped one another to learn one of the four subunits, with two groups devoted to each of the four subunits. Seventhly, after students had helped each other to learn their learning materials, they were requested to return to their home groups to teach other members what they learned from their experience in the jigsaw groups. Finally, the instructor assessed understanding of the entire unit through students' presentations in front of the whole class. This whole process was repeated six times, once for each unit of work.

Throughout the study, both groups were taught by the researcher, an MAE instructor. The experimental group was conducted on Mondays, while the control group was on Tuesdays. Both groups covered the same MAE content and received MAE instruction for the same amount of time in the mornings, and in the same room. All students in both groups participated in one instructional session of 150 minutes per week for each unit over the six weeks. All the tests measuring achievement are identical. After the treatment, both groups took a post-test in the seventh week, and a delay test in the tenth week. Also, two questionnaires were given, one to both groups to measure the perceptions of instruction, and one, given to the treatment group only, to measure attitudes toward jigsaw learning.

\subsection{Data Collection and Analysis}

Data analyzed comprised the test scores, responses to the questionnaire which evaluated the instruction, and the results of the attitude questionnaire toward jigsaw learning. The following analyses were undertaken to examine the research hypotheses. A one-way ANOVA was performed to compare the means of the pre-test scores of the groups before the treatment. An analysis of covariance (ANCOVA) was used to compare the groups' post-test and retention test scores, using the pre-test as a covariate. Bonferroni pairwise comparisons were used to determine significant differences between the groups. A repeated-measures analysis of variance (MANOVA) was performed to compare the mean scores of the four scales measuring different aspects of the instruction. Bonferroni pairwise contrasts were used to determine significant differences between groups in their mean score on each of the four scales. All analyses were tested for significance at the .05 level. Responses of the forty students to the two open questions on the attitude survey were analyzed qualitatively. An analysis of the content was used to identify themes in students' responses, to develop categories of responses based on common themes, and to tabulate the number and percentage of frequent responses for each category.

\section{Results}

\subsection{Achievement}

The results of the ANOVA show no statistically significant difference in MAE pre-test scores $(\mathrm{F}(1,78)=.556$; $\mathrm{p}>.05)$ of the experimental group $(\mathrm{M}=6.61, \mathrm{SD}=.88, \mathrm{~N}=40)$ and the control group $(\mathrm{M}=6.76, \mathrm{SD}=.91, \mathrm{~N}=40)$. These results show that students in both groups had similar academic knowledge on the MAE before the experiment commenced. The findings obtained from the one-way ANCOVA analysis on the MAE post-test scores, with MAE pre-test scores as the covariate, showed a significant difference $(\mathrm{F}(1,77)=8.43, \mathrm{p}=.005)$. The magnitude of the pairwise comparison indicated that the adjusted means post-test of the experimental group ( $\mathrm{Madj}=7.84, \mathrm{SE}=.11)$ is significantly different $(\mathrm{p}<.05)$ from that of the control group $(\mathrm{Madj}=7.38, \mathrm{SE}=.11)$. The results showed that the experimental group, which had engaged in jigsaw learning produced a higher overall improvement in scores on the MAE post-test $(\mathrm{p}=.005)$ when adjusted for pre-test scores.

\subsection{Knowledge Retention}

Results of the one-way ANCOVA on the MAE delay test scores, with MAE pre-test scores as the covariate, showed a significant difference $(\mathrm{F} 1,77)=10.07, \mathrm{p}=.002)$. The magnitude of the pairwise comparison indicates that at the overall .05 level, the adjusted means of the delay test of the experimental group (Madj $=7.80, \mathrm{SE}=.10$ ) is significantly different $(\mathrm{p}<.05)$ from that of the control group $(\mathrm{Madj}=7.32, \mathrm{SE}=.10)$. The results showed that the experimental group produced a higher overall improvement in scores on the MAE delay test $(\mathrm{p}=.002)$ when adjusted for pre-test scores. 


\subsection{Perception of Instruction}

The multivariate tests for differences in means in the repeated-measures MANOVA found that the pattern of students' responses to the four aspects of instruction differ significantly $(F(3,76)=72.73, p=.000)$. Not only are their responses to each of the four scales not equivalent, the different varies by group $(\mathrm{F}(3,76)=11.65, \mathrm{p}=.000)$. The pairwise contrasts within subjects indicate at the overall .05 level that there are significant differences in means between $\mathrm{SCL}$ and PT $(\mathrm{MSCL}=2.97, \mathrm{SD}=.43$ and $\mathrm{MPT}=3.80, \mathrm{SD}=.70 ; \mathrm{F}=105.12, \mathrm{p}=.000)$, SCL and $\mathrm{EL}$ (MEL $=3.79, \mathrm{SD}=.61 ; \mathrm{F}=128.48, \mathrm{p}=.000)$, and SCL and GTS $(\mathrm{MGTS}=3.91, \mathrm{SD}=.77 ; \mathrm{F}=110.39, \mathrm{p}=.000)$. However, no significant differences were found between EL and GTS $(F=1.10, p=.296)$, GTS and PT $(F=1.57, p$ $=.214)$, and PT and EL $(\mathrm{F}=.001, \mathrm{p}=.970)$. The results of the factor by treatment interaction yielded the same findings. There were significant differences in means between SCL and PT $(F=20.14, p=.000)$, SCL and EL $(F=$ $22.43, \mathrm{p}=.000)$, and SCL and GTS $(\mathrm{F}=14.33, \mathrm{p}=.000)$. However, no significant differences in means were found between EL and GTS $(\mathrm{F}=.00, \mathrm{p}=.959)$, GTS and PT $(\mathrm{F}=.06, \mathrm{p}=.796)$, and PT and EL $(\mathrm{F}=.45, \mathrm{p}=.832)$. As shown in Figure 1 below, although there are no significant differences between the groups with regard to their perceptions of three of the aspects of instruction, namely EL, GTS and PT, the means score of the experiment group on the measure "SCL" $(M=3.32)$ is significantly higher than that of the control group $(M=2.62)$.

Insert Figure 1 here

\subsection{Attitudes}

As indicated above, all forty students in the treatment group completed the questionnaire assessing their attitude to learning via jigsaw grouping. The first question asked students to indicate the degree of enjoyment that students experienced in jigsaw learning. Inspection of their responses shows that thirty students $(77.5 \%)$ liked jigsaw learning a lot, seven students (17.5\%) liked it a little, only two students (5\%) were not sure whether or not they liked this learning, and no-one disliked it. For the last two open questions, students were asked if there was anything they liked or disliked about jigsaw learning. Table 2 below reports the relevant findings for each of the two items. Since some individual responses contained more than one theme, they were coded and counted in more than one category. Hence, the percentages shown in the table were based on the number of different responses and not on the number of students who completed the questionnaire. The most frequent responses were that students liked working together and getting help from others (62.5\%), discussing and sharing information $(42.5 \%)$, teaching others $(22.5 \%)$, and they appreciated mutual help among students (22.5\%). Students also perceived that they improved their learning skills in terms of critical thinking and oral communication (17.5\%). Finally, students responded that jigsaw learning creates an enjoyable learning environment (15\%), promotes positive relationships among participants (12.5\%), and improves confidence $(12.5 \%)$.

When students were asked what they disliked about jigsaw learning, they generally said that there was nothing to dislike (67.5\%), or that they liked it all (72.5\%). However, some students felt left behind (7.5\%); others disliked pre-assigned groups $(7.5 \%)$; some students complained about uncooperative group members $(5 \%)$; others cited irresponsible group members (5\%); and one student (2.5\%) expressed concern about shy group members.

Insert Table 3 here

\section{Discussion}

The purpose of this study was to investigate the effects of jigsaw learning on students' achievement, knowledge retention, perception of instruction, and their attitudes toward this kind of learning. As presented the results indicate no significant differences in MAE pre-test scores between the groups (before the treatment). However, post treatment results (with pre-test controlled) indicate that jigsaw learning has more positive effects on achievement, and knowledge retention than teacher-centered instruction. The students in the experimental group perceived their instruction as more cooperative and more student-centered than did those in the control group, although no different in terms of more generic aspects of instruction. Finally, students' attitudes towards jigsaw learning are overwhelmingly positive.

\subsection{Achievement}

Results indicate that the groups differ significantly $(\mathrm{F}(1,77)=8.43 ; \mathrm{p}<.05)$ on their post experiment achievement. This finding supports the first hypothesis which states that students who participate in jigsaw learning will achieve higher scores than those taught through lecture-based teaching. According to the students' reports, the main reasons for improvement in achievement in the experimental group appear to be the frequent reciprocal interaction among participants around interactive learning tasks, and the active role of participants. Deutsch (1949) argues that social interdependence results in reciprocal interaction. Through such interaction each student's goals in cooperative situations are determined under the influence of the actions of other students (Johnson \& Johnson, 2009). In the 
jigsaw group students had higher achievement than those in the control group because they had more opportunities for mutual help, exchange of needed resources, effective communication, and mutual influence (Johnson \& Johnson, 2008). In addition, cognitive processes are outcomes of cultural and social interactions in an active learning environment (Piaget, 1926; Vygotsky, 1978; Slavin, 2011). Therefore, as a result of frequent reciprocal interaction with their partners, students were able to fully develop their new knowledge based on their current knowledge, while undertaking interactive learning tasks.

Furthermore, students progressed at their own pace and developed their potential because they observed and imitated the desired behaviors of effective students in the jigsaw group (Bandura, 1977; Schunk, 2007). These findings also corresponded with the constructivist learning theory in which learners are in control of constructing their own meaningful knowledge through interaction with their environment (Bruner, 1966; Dewey, 1991; Brooks \& Brooks, 1999; Yager, 2000; Almala, 2005). From such a constructivist perspective, students improved their achievement because they were active agents in constructing their own knowledge (Driscoll, 2000; Marlow \& Page, 2005). This interpretation is well supported by the findings obtained from both survey questionnaires, which show that students in the experimental group believed that they learned most from working with others and getting help, and they perceived the instruction as more interactive, cooperative and more student-centered. The results of this study are consistent with the findings of previous research (Yamarik, 2007; Kilic, 2008; Doymus, 2008a\&b, Doymus et al., 2010; Sahin, 2010) which indicate that jigsaw learning results in higher academic achievement.

\subsection{Knowledge Retention}

Results also indicate a significant group difference $(F(1,77)=10.07 ; p<.05)$ in knowledge retention, whereby students who participated in jigsaw learning had greater retention of information than those who had lecture-based teaching. This finding is compatible with the argument of Sousa (2006) reported earlier, that the retention rate for material learned increases when students teach others. Slavin (2011) claims that if students are given opportunities to elaborate upon the material and offer explanation to others, information will be retained in memory and related to information already in memory. Explaining the material to others is one of the most effective means of elaboration (Kagan \& Kagan, 2009; Slavin, 2011). From the perspective of cognitive elaboration, some researchers (O'Donnell, 1996 \& 2000; Webb, 2008) claim that the effectiveness of learning and knowledge retention depends on the level of cognitive elaboration between group members. Consequently, it is consistent that students in the jigsaw group achieved and retained more knowledge because they offered explanations to others (Zakaria et al., 2010).

In addition, students in the treatment group spent more time on preparing the learning materials, discussing learning issues with their peers, and teaching their peers. The increase in time spent on these tasks has been argued to lead to an in-depth understanding and retention of learning materials (Johnson \& Johnson, 2002; Beck \& Chizhik, 2008). The findings obtained from the attitude survey support this interpretation, since students in the treatment group valued the effectiveness of discussing and sharing information, and teaching others in groups. The findings of this study supported the results reported from recent studies (Iqbal, 2004; Mehra \& Thakur, 2008; Chianson et al., 2010; Kvam, 2000; Tanel \& Erol, 2008; Nassal, 2009; Nichols, 2002; Webb, 2008) that indicate that students yielded better mean gains on retention scores through cooperative learning than via conventional group learning.

\subsection{Perception of Instruction}

Results support the third hypothesis that; students' perception of the quality of their instruction will not differ, whether taught by jigsaw learning or taught through lecture-based teaching. The students in both groups have similar perceptions of much of the instruction. They do not differ significantly for three of the four, more generic, components of instruction, namely GTS, EL, or PT. The students in both groups perceived the teacher's teaching skills as effective. The instructor helped students comprehend the MAE content well by organizing lessons systematically, asking questions to check students' understanding, and giving satisfactory answers. The students also valued the teacher's efforts in facilitating their appreciation of the learning material. The instructor made the lessons interesting, and encouraged students to ask questions. In addition, students perceived the teacher as knowledgeable and enthusiastic about the subject, and they were pleased with how much they were learning. Such positive perceptions on these three instructional factors indicate that the instructor who taught the MAE to both groups was not biased against students in the control group.

However, students in both groups have different perceptions regarding the SCL component of the instruction, results which strongly support the fourth hypothesis. The students in the experimental group perceived their instruction as more cooperative and more student-centered than did those in the control group. The former students reported more learning in groups, more helping and teaching each other, more discussing the learning material among participants as well as a greater exchange of information. These perceptions of instruction are compatible with the nature of CL in which students work together to maximize their own learning and others' learning (Slavin, 2011). This validates 
the jigsaw learning treatment in the experimental group. Consequently the recorded improvement in achievement and knowledge retention and the students' positive attitudes toward their learning are the results of the treatment, not the instructor in the experiment.

\subsection{Attitudes}

Results strongly support the fifth hypothesis that students who are taught by jigsaw learning will have positive attitudes towards this learning. The vast majority of students in the experimental group liked the way they were 'taught'. Specifically, most students liked working with others and getting help, discussing and sharing information with others, teaching others, helping one another, and enjoying the jigsaw context. These results are consistent with student responses to CL reported by other researchers (Mulryan, 1994; Nattiv; 1994, Whicker \& Nunnery, 1997; Vaughan, 2002; Sahin, 2010; Le, 2010; Thanh-Pham, 2011). Other students stated that jigsaw learning promoted friendly relationships among participants, and improved learning skills as well as their self-esteem. These findings clearly support several previous studies which show that CL groups result in positive relationships among participants (Vaughan, 2002; Johnson \& Johnson, 2005), and enhance learning skills and self-esteem (Lampe, Rooze \& Tallent-Runnels, 1996; Johnson, 2009; Bertucci et al., 2010). These positive outcomes occurred in the cooperative group because students were given opportunities to develop social skills (Bertucci et al., 2010), experience various solutions for different ideas (Abrami \& Chambers, 1996), and experience achievement in learning (Kilic, 2008). In summary, students had positive attitudes toward their learning since they were socially, academically and psychologically successful (Johnson \& Johnson, 2008). However, the results of the study also show that some students disliked permanent groups, uncooperative group members, irresponsible group members, and shy group members, while some students felt left behind in the learning process. The changes which were consistently suggested by students were to rotate group members.

\section{Conclusion}

CL advanced the academic and social growth of a sample of Vietnamese students because it provided an interactive approach for learning. This study claims that the frequent reciprocal interaction among participants in the treatment group stimulated cognitive activities, promoted higher levels of achievement and retention, and enhanced positive attitudes toward learning. This study supported the findings of previous studies from different cultures, and demonstrates that $\mathrm{CL}$ is an effective teaching approach. In this study, the effectiveness of CL on students is compatible with the requirements of teaching innovation in VHEI (MOET, 2009). The findings provide Vietnamese teachers with more empirical support for promoting productive changes in teaching methods to improve student learning and their attitudes toward learning (NASRV, 2008). Thus, CL is highly recommended as an alternative instructional pedagogy in the current wave of educational reform in Vietnamese schools, especially in relation to the aim of making the learning environment more stimulating for students. The emphasis on lower-order thinking competencies in lecture-based teaching may be transformed by CL experiences into higher-order thinking competencies. The traditional activities of teachers lecturing and students listening may also be transformed into cooperative activities where students actively construct knowledge. Moreover, the traditional dependence on teachers, where students work on their own for good marks, can be augmented, or replaced, by CL where students work in groups to achieve shared goals (Liang, 2002). Both teachers and students in VHEI should be encouraged to practice CL frequently. Although the present findings support the effectiveness of CL for achievement and attitudes, the sample in this study is restricted to only 80 participants. Therefore, future studies should apply CL with more participants to generate more evidence on the effects of CL. As only a few research studies have investigated the effectiveness of CL in higher education in Vietnam, the findings of this study are not sufficient to decide on the optimal use of CL at all levels of education in Vietnam. Thus, a series of further studies on CL at primary and secondary levels of Vietnamese education should be undertaken.

\section{References}

Abrami, P. C., \& Chambers, B. (1996). Research on co-operative learning and achievement: comments on Slavin. Contemporary Educational Psychology, 21(1), 70-79. http://dx.doi.org/10.1006/ceps.1996.0005

Adeyemi, B. A. (2008). Effects of cooperative learning and problem-solving strategies on Junior Secondary School Students' Achievement in Social Studies. Electronic Journal of Research in Educational Psychology, 6(3), 691-708

Almala, A. H. (2005). A Constructivist Conceptual Framework for a Quality e-Learning Environment. Distance Learning, 2(5), 9-12

Aronson, E., Blaney, N., Stepan, C., Sikes, J., \& Snapp, N. (1978). The jigsaw classroom. (2rd ed.). Beverley Hills, CA: Sage. 
Ary, D., Jacobs, L. C., \& Razavieh, A. (2002). Introduction to Research in Education. (6th ed.). Belmont, CA: Wardsworth/Thomson Learning.

Bandura, A. (1977). Social Learning Theory. (3rd ed.). Englewood Cliffs, NJ: Prentice Hall Regents.

Basit, T. N. (2010). Conducting Research in Educational Contexts. (1st ed.). New York: Continuum International Publishing Group.

Beck, L. L., \& Chizhik, A. W. (2008). An experimental study of cooperative learning in CS1. In Proceedings of the 39th SIGCSE technical symposium on Computer science education (pp. 205-209). New York: ACM. http://dx.doi.org/10.1145/1352135.1352208

Bertucci, A., Conte, S., Johnson, D. W., \& Johnson, R. T. (2010). The impact of size of cooperative group on achievement, social support, and self-esteem. The Journal of General Psychology, 137(3), 256-271. http://dx.doi.org/10.1080/00221309.2010.484448

Best, J. W., \& Kahn, J. V. (1998). Research In Education. (8th ed.). Boston: Allyn and Bacon.

Brooks, M. G., \& Brooks, J. G. (1999). The Courage to be constructivist. Educational Leadership, 57(3), 18-24.

Bruner, J. (1966). Toward a theory of instruction. Cambridge, MA: Harvard University Press.

Chianson, M. M., Kurumeh, M. S., \& Obida, J. A. (2010). Effect of cooperative learning strategy on students' retention in circle geometry in secondary schools in Benue State, Nigeria. American Journal of Scientific and Industrial Research, 2(1), 33-36. http://dx.doi.org/10.5251/ajsir.2011.2.1.33.36

Creswell, J. W. (2009). Research Design: Qualitative, Quantitative, and Mixed Methods Approach. (3rd ed.). London: Sage Publications, Inc. http://dx.doi.org/10.1207/s15430421tip3903_2

Creswell, J. W., \& Miller, D. L. (2000). Determining Validity in Qualitative Inquiry. Theory Into Practice, 39(3), $124-130$

Department of Education and Skills [DES]. (2003). The future of higher education, London: The Stationary Office Limited.

Deutsch, M. (1949). A theory of cooperation and competition. Human Relations, 2(2), 129-152. http://dx.doi.org/10.1177/001872674900200204

Dewey, J. (1991). Exeprience and education. In A. Boydston (Ed.), Johnson Dewey: The later works, 1938-1939 (pp. 1-62). Carbondale, II: Siu Press.

Director, S. W., Doughty, P., Gray, P. J., Hopcroft, J. E., \& Silvera, I. F. (2006). Observations on undergraduate education in computer science, electrical engineering, and physics at select universities in Vietnam (A report presented to the Vietnam Education Foundation by the Site Visit Teams of the National Academies of the United States). Ha Noi: Vietnam Education Foundation. [Online] Available: http://www.home.vef.gov/download/Report_on_Undergrad_Educ_V.pdf (April 9, 2009)

Doymus, K. (2008a). Teaching chemical bonding through jigsaw cooperative learning. Research in Science \& Technological Education, 26(1), 47-57. http://dx.doi.org/10.1080/02635140701847470

Doymus, K. (2008b). Teaching Chemical Equilibrium with Jigsaw Technique. Research in Science Education, 38(2), 249-260. http://dx.doi.org/10.1007/s11165-007-9047-8

Doymus, K., Karacop, A., \& Simsek, U. (2010). Effects of jigsaw and animation techniques on students' understanding of concepts and subjects in electrochemistry. Educational Technology Research and Development, 58(6), 671-691. http://dx.doi.org/10.1007/s11423-010-9157-2

Driscoll, M. P. (2000). Psychology of learning for instruction. (2nd ed.). Boston: Allyan \& Bacon.

Gillies, R. M. (2006). Teachers' and students' verbal behaviors during cooperative and small-group learning. British Journal of Educational Psychology, 76(2), 271-287. http://dx.doi.org/10.1348/000709905X52337

Iqbal, M. (2004). Effects of cooperative Learning on Academic Achievement of Secondary School Students in Mathematics (Doctoral dissertation, University of Arid Argiculture. Rawalpindi, Pakistan). [Online] Available: http://www.prr.hec.gov.pk/Thesis/239.dpf (June 9, 2010)

Johnson, A. W., \& Johnson, R. (2002). Cooperative Learning Methods: A meta-analysis. Journal of Research in Education, 12(1), 5-14

Johnson, D. W. (2003). Social Interdependence: The Interrelationships among theory, research, and practice. American Psychologist, 58(11), 931-945. http://dx.doi.org/10.1037/0003-066X.58.11.934 
Johnson, D. W. (2009). Reaching out: Interpersonal effectiveness and self-actualization. (10th ed.). Boston: Allyn \& Bacon.

Johnson, D. W., \& Johnson, F. (2006). Joining Together: Group Theory and group skills. (7th ed.). Boston: Allyn \& Bacon.

Johnson, D. W., \& Johnson, R. (2005). New Developments in Social Interdependence Theory. Genetic, Social, \& General Psychology Monographs, 131(4), 285-358. http://dx.doi.org/10.3200/MONO.131.4.285-358

Johnson, D. W., \& Johnson, R. T. (2008). Social Interdependence Theory and Cooperative Learning: The Teacher's Role. In R. M. Gillies, A. Ashman \& J. Terwel (Eds.), Teacher's Role in Implementing Cooperative Learning in the Classroom (pp. 9-37). New York, U.S.A: Springer. http://dx.doi.org/10.1007/978-0-387-70892-8_1

Johnson, D. W., \& Johnson, R. T. (2009). An Educational Psychology Success Story: Social Interdependence Theory and Cooperative Learning. Educational Researcher, 38(5), 365-379. http://dx.doi.org/10.3102/0013189X09339057

Johnson, D. W., \& Johnson, T. R. (1999). Cooperative Learning and Achievement. In D. Kluge, S. McGuire, D. Johnson \& R. Johnson (Eds.), Cooperative Learning: JALT Applied Materials (pp. 23-37). New York: Greenwood Press, Inc.

Kagan, S., \& Kagan, M. (2009). Kagan Cooperative Learning (1st ed.). San Clemente, CA: Kagan Publishing.

Kilic, D. (2008). The Effects of the Jigsaw Technique on Learning the Concepts of the Principles and Methods of Teaching. World Applied Sciences Journal, 4(1), 109-114

Kose, S., Sahin, A., Ergun, A., \& Gezer, K. (2010). The effects of cooperative learning experience on eighth grade students' achievement and attitude toward science. Education, 131(1), 169-180

Kvam, P. H. (2000). The Effects of Active Learning Methods on Student Retention in Engineering Statistics. The American Statistician, 54(2), 136-140. http://dx.doi.org/10.2307/2686032

Lampe, J. R., Rooze, G. E., \& Tallent-Runnels, M. (1996). Effects of Cooperative Learning Among Hispanic Students in Elementary Social Studies. The Journal of Educational Research, 89(3), 187-191. http://dx.doi.org/10.1080/00220671.1996.9941324

Le, T. T. (2010). Infusing Cooperative Learning into An EFL Classroom. English Language Teaching, 3(2), 64-77

Liang, T. (2002). Implementing Cooperative Learning in EFL Teaching: Process and Effects (Doctoral dissertation, National Taiwan Normal University). [Online] Available: http://www.asian-efl-journal.com/Thesis_Liang_Tsailing.pdf(July 17, 2009)

Magnesio, S., \& Davis, B. H. (2010). A Novice Teacher Fosters Social Competence with Cooperative Learning. Childhood Education, 86(4), 216-223

Marlow, B. A., \& Page, M. L. (2005). Creating and sustaining the constructivist classroom. (2nd ed.). Thousand Oaks, CA: Corwin Press.

Mehra, V., \& Thakur, K. (2008). Effects of Cooperative Learning on Achievement and Retention in Mathematics of Seventh Graders with different Cognitive Styles. Indian Educational Review, 44(1), 5-31

Ministry of Education and Training of Vietnam [MOET] (2009). Development Strategy from 2009 to year 2020 for the Cause of Industrialization and Modernization of Vietnam. Hanoi: Vietnamese Government.

Mulryan, C. M. (1994). Perceptions of intermediate students' cooperative small-group work in mathematics. The Journal of Educational Research, 87(5), 280-291. http://dx.doi.org/10.1080/00220671.1994.9941255

Nassal, S. H. (2009). Effectiveness of Cooperative Learning on Girls' Achievement and Retention in the Course of General Teaching and Training Methods: A Field Experimental Study in Dubai Branch of Al-Quds open University. Damuascus University Journal, 25(1+2), 335-360

National Assembly of the Socialist Republic of Vietnam [NASRV] (2008). Education Law, No. 38/2008/QH11-2008. Hanoi: Education Press.

Nattiv, A. (1994). Helping Behaviors and Math Achievement Gain of Students Using Cooperative Learning. The Elementary School Journal, 94(3), 285-297. http://dx.doi.org/10.1086/461767

Neuman, W. L. (2006). Social Research Methods: Qualitative and Quantitative Approaches. (6th ed.). Boston: Pearson Education, Inc. 
Nhu-Le, T. (1999). A Case Study of Cooperative Learning in Inorganic Chemistry Tutorials at the Vietnam National University-Ho Chi Minh City (Master dissertation, University of Simon Fraser, Canada). [Online] Available: http://www.ir.lib.sfu.ca/bitstream/1892/8731/1/b19483041.pdf (March, 19, 2010)

Nichols, J. D. (2002). The Effects of Cooperative Learning on Students' achievement and Motivation in High School Geometry Class. [Online] Available: http://www.eric.ed.gov/PDFS/ED387341.pdf (October 9, 2010)

O'Donnell, A. M. (1996). The effects of explicit incentives on scripted and uncripted cooperation. Journal of Educational Psychology, 88(1), 74-86. http://dx.doi.org/10.1037/0022-0663.88.1.74

O'Donnell, A. M. (2000). Interactive effects of prior knowledge and material format on cooperative teaching. Journal of Experimental Education, 68(2), 101-108. http://dx.doi.org/10.1080/00220970009598497

Piaget, J. (1926). The language and thought of the child. (1st ed.). New York: Harcourt Brace.

Ross, S. M., Morrison, G. R., \& Lowther, D. L. (2005). Using Experimental Methods in Higher Education Research. Journal of Computing in Higher Education, 16(2), 39-64. http://dx.doi.org/10.1007/BF02961474

Sahin, A. (2010). Effects of Jigsaw III technique on achievement in written expression. Asia Pacific Education Review, 12(3), 427- 435. http://dx.doi.org/10.1007/s12564-010-9135-8

Schunk, D. H. (2007). Learning theories: An Educational Perspective. (4th ed.). Upper Saddle River, NJ: Pearson Education.

Slavin, R. E. (1990). Cooperative learning: Theory, research, and practice. (2nd ed.). New Jersey: Prentice Hall.

Slavin, R. E. (1996). Research on co - operative learning and achievement: What we know, what we need to know. Contemporary Educational Psychology, 21(4), 43-69. http://dx.doi.org/10.1006/ceps.1996.0004

Slavin, R. E. (2011). Instruction Based on Cooperative Learning. In R. E. Mayer \& P. A. Alexander (Eds.), Handbook of Research on Learning and Instruction (pp. 344-360). New York: Taylor \& Francis.

Sousa, D. A. (2006). How the brain learns (3rd ed.). Heatherton, Vic: Hawker Brownlow Education.

Suter, W. N. (2006). Introduction to Educational Research: A Critical Thinking Approach. (1st ed.). Thousand Oaks: Sage Publications.

Tanel, Z., \& Erol, M. (2008). Effects of Cooperative Learning on Instructing Magnetism: Analysis of an Experimental Teaching Sequence. American Journal of Physics and Education, 2(2), 124-136

Thanh-Pham, T. (2010a). Group Composition of Cooperative Learning: Does Heterogeneous Grouping Work in Asian Classrooms? International Education Studies, 3(3), 12-19

Thanh-Pham, T. (2010b). Implementing a Student-Centered Learning Approach at Vietnamese Higher Education Institutions: Barriers under Layers of Casual Layered Analysis (CLA). Journal of Futures Studies, 15(1), 21-38

Thanh-Pham, T. (2011). An Investigation of Perceptions of Vietnamese Teachers and Students toward Cooperative Learning. International Education Studies, 4(1), 3-12

Vaughan, W. (2002). Effects of Cooperative Learning on Achievement and Attitude Among Students of Color. The Journal of Educational Research, 95(6), 359-364. http://dx.doi.org/10.1080/00220670209596610

Vygotsky, L. S. (1978). Mind in society: the development of higher psychological processes. Cambrigde: Harward University Press.

Webb, N. M. (2008). Learning in small groups. In T. L. Good (Ed.), 21st Century education: A reference handbook (pp. 203-211). Los Angeles: Sage.

Whicker, K. M., Bol, L., \& Nunerery, J. A. (1997). Cooperative learning in the Secondary Mathematics Classroom. The Journal of Educational Research, 91(1), 42-48. http://dx.doi.org/10.1080/00220679709597519

Yager, R. E. (2000). The Constructivist Learning Model. The Science Teacher, 67(1), 44-45.

Yamarik, S. (2007). Does cooperative learning improve student learning outcomes? (Research in Economic Education)(Report). The Journal of Economic Education, 38(3), 259-277. http://dx.doi.org/10.3200/JECE.38.3.259-277

Zain, Z. M., Subramaniam, G., Rashid, A. A., \& Ghani, E. K. (2009). Teaching Students' Performance and Attitude. Canadian Social Science, 5(6), 92-102 
Zakaria, E., Chin, L. C., \& Daud, Y. (2010). The Effects of Cooperative Learning on Students' Mathematics Achievement and Attitude toward Mathematics. Journal of Social Sciences, 6(2), 272-275. http://dx.doi.org/10.3844/jssp.2010.272.275

Table 1. Instruction Factors, Description, Number of Items \& Cronbach's Alpha Values

\begin{tabular}{|c|c|c|c|}
\hline Factors & Description & $\begin{array}{l}\text { No. of } \\
\text { items }\end{array}$ & $\begin{array}{c}\text { Reliability } \\
\text { values }\end{array}$ \\
\hline 1. GTS & $\begin{array}{l}\text { Students' perception of generic teaching skills of the teacher } \\
\text { (e.g. teacher organized the lesson well, teacher gave satisfactory } \\
\text { answers to students' questions.) }\end{array}$ & 10 & .92 \\
\hline 2. SCL & $\begin{array}{l}\text { Students' perception of CL activities and positive relationships } \\
\text { among students in learning } \\
\text { (e.g. students exchanged information, students taught each other.) }\end{array}$ & 9 & .77 \\
\hline 3. EL & $\begin{array}{l}\text { Students' perception of the teacher's efforts to facilitate students' } \\
\text { appreciation and understanding of the learning material } \\
\text { (e.g. teacher made the information easy for students to } \\
\text { understand, teacher made the information interesting.) }\end{array}$ & 4 & .75 \\
\hline 4. $\mathrm{PT}$ & $\begin{array}{l}\text { Students' perception of satisfaction with the professional capacity } \\
\text { of the teacher } \\
\text { (e.g. students were pleased with how much they were learning, } \\
\text { teacher seemed knowledgeable.) }\end{array}$ & 3 & .70 \\
\hline
\end{tabular}

Table 2. The Pre-test-Post-test Nonequivalent Comparison-Group Design

\begin{tabular}{|c|c|c|c|c|c|c|}
\hline Participants & $\begin{array}{l}\text { Matched } \\
\text { Sampling }\end{array}$ & Group & Pre-test & Treatment & Post-test & Delay test \\
\hline \multirow[t]{2}{*}{$\begin{array}{l}\text { All of the } \\
\text { final-year } \\
\text { mathematics } \\
\text { students of } \\
\text { university } \\
\text { ( } 80 \text { students) }\end{array}$} & $\begin{array}{l}\text { Matched } \\
\text { sampling of } 40 \\
\text { students } \\
\text { Experimental } \\
\text { group based on } \\
\text { age, gender and } \\
\text { GPA scores }\end{array}$ & $\begin{array}{l}\text { Exp. } \\
(40 \\
\text { students) }\end{array}$ & $\begin{array}{l}\text { O1 } \\
\text { Contents } \\
\text { of MAE }\end{array}$ & $\begin{array}{l}\text { X1 } \\
\text { Jigsaw } \\
\text { learning } \\
\text { pedagogy } \\
\text { (Independent } \\
\text { variable) }\end{array}$ & $\begin{array}{l}\text { O2 } \\
\text { - Contents of } \\
\text { MAE } \\
\text { - Perception of } \\
\text { instruction } \\
\text { - Attitudes } \\
\text { toward jigsaw } \\
\text { learning } \\
\text { (Dependent } \\
\text { variables) }\end{array}$ & $\begin{array}{l}\text { O3 } \\
\text { Contents of } \\
\text { MAE } \\
\text { (Dependent } \\
\text { variable) }\end{array}$ \\
\hline & $\begin{array}{l}\text { Matched } \\
\text { sampling of } 40 \\
\text { students } \\
\text { Experimental to } \\
\text { group based on } \\
\text { age, gender and } \\
\text { GPA scores }\end{array}$ & $\begin{array}{l}\text { Con. } \\
(40 \\
\text { students) }\end{array}$ & $\begin{array}{l}\text { O4 } \\
\text { Contents } \\
\text { of MAE }\end{array}$ & $\begin{array}{l}\text { X2 } \\
\text { Lecture-based } \\
\text { teaching } \\
\text { pedagogy } \\
\text { (Independent } \\
\text { variable) }\end{array}$ & $\begin{array}{l}\text { O5 } \\
\text { - Contents of } \\
\text { MAE } \\
\text { - Perception of } \\
\text { instruction } \\
\text { (Dependent } \\
\text { variables) }\end{array}$ & $\begin{array}{l}\text { O6 } \\
\text { Contents of } \\
\text { MAE } \\
\text { (Dependent } \\
\text { variable) }\end{array}$ \\
\hline
\end{tabular}

\section{Con: Control Group}

Exp: Experimental Group

MAE: Management of Administration and Education

$\mathrm{X} 1$ : jigsaw learning pedagogy

$\mathrm{X} 2$ : lecture-based teaching pedagogy

O1 O4: Pre-test on MAE

O2 O5: - Post-test on MAE

- Perception of instruction

- Attitudes toward jigsaw learning 
O3 O6: Delay test on MAE

Table 3. Students' most frequent responses to the two 'open' questions.

\begin{tabular}{|l|c|c|}
\hline $\begin{array}{l}\text { Was there anything in particular that you found enjoyable } \\
\text { in the jigsaw process? Give details? }\end{array}$ & No. of students & Percentages \\
\hline Learning most from working with others and getting help & 25 & 62.5 \\
\hline Discussing and sharing information & 17 & 42.5 \\
\hline Effectiveness of teaching others & 9 & 22.5 \\
\hline Mutual help among students & 9 & 22.5 \\
\hline Improvement in learning skills & 8 & 20.0 \\
\hline Enjoyable learning context & 7 & 17.5 \\
\hline Friendly relationships & 6 & 12.5 \\
\hline Improved confidence & 5 & Percentages \\
\hline $\begin{array}{l}\text { Was there anything in particular that you did not enjoy in } \\
\text { doing the jigsaw process? Give details? }\end{array}$ & No. of students & 67.5 \\
\hline Nothing to dislike & & 72.5 \\
\hline Liked it all & 27 & 7.5 \\
\hline Feeling left behind & 29 & 7.5 \\
\hline Pre-assigned groups & 3 & 5.0 \\
\hline Uncooperative members & 3 & 5.0 \\
\hline Irresponsible members & 2 & 2.5 \\
\hline Shy members & 2 & \\
\hline
\end{tabular}

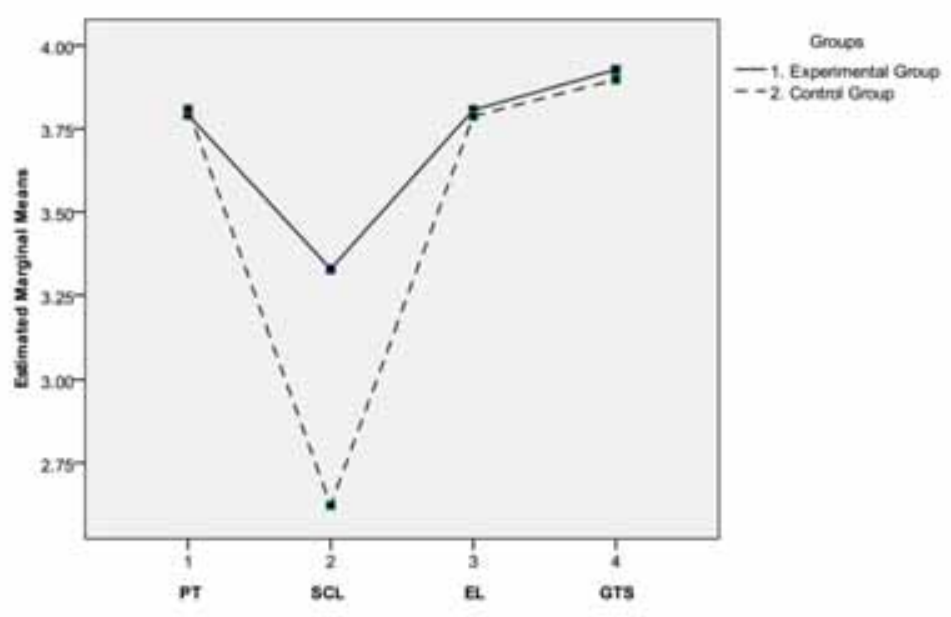

Figure 1. Plot of Means for Factor Data 